\title{
The Correlation of the Level of Anxiety of Nulliparous Women to the Length of First Stage of Spontaneous Labor at Private Maternity Clinics in the Working Area of Delitua Puskesmas, Deli Serdang District in 2013
}

\author{
${ }^{1}$ Namora Lumongga Lubis, ${ }^{2}$ Megawati Sinambela \\ ${ }^{1}$ Public Health Faculty Universitas Sumatera Utara, Medan, Indonesia \\ ${ }^{2}$ Institute of Health Science Deli Husada, Deli Serdang
}

\begin{tabular}{|c|c|}
\hline & ABSTRACT \\
\hline $\begin{array}{l}2016 \text { Research Leap/Inovatus Services Ltd. } \\
\text { All rights reserved. } \\
\text { DOI: } 10.18775 / \text { jibrm.1849-8558.2015.43.3004 } \\
\text { URL: http://dx.doi.org/10.18775/jibrm.1849- } \\
\text { 8558.2015.43.3004 }\end{array}$ & $\begin{array}{l}\text { Abnormal length of first stage of labor in nulliparous women (first pregnancy) can be related by } \\
\text { severe anxiety during labor. Based on the preliminary survey in several private maternity clinics at } \\
\text { the working area of Delitua Puskesmas, Deli Serdang District, it was found that there was a } \\
\text { prolonged first stage of labor ( } 27.65 \% \text { ) in nulliparous women. The purpose of this study was to } \\
\text { analyze the influence of anxiety level to the lenght of first stage of labor. The type of this study was } \\
\text { an analytic survey with explanatory research type. The samples comprised } 40 \text { childbearing women }\end{array}$ \\
\hline $\begin{array}{l}\text { Keywords: } \\
\text { Level of anxiety, Nulliparous women, Length of } \\
\text { first stage of labor }\end{array}$ & $\begin{array}{l}\text { the working area of Delitua Puskesmas, Deli Serdang District,using accidental sampling technique. } \\
\text { The data were gathered by using questionnaires and analyzed in univariet analysis by using } \\
\text { frequency distribution form, and bivariate analysis using Chi Square test. The result of this study } \\
\text { showed that the level of anxiety ( } \mathrm{p}=0.001 \text { ) significantly related the lenght of first stage of labor } \\
\text { in which mothers who had severe anxiety. It is recomended that health providers should provide } \\
\text { standardized services to childbearing women, especially to nulliparous women, so that their level } \\
\text { of anxiety can be decreased facing the first stage of labor process. It is also recommended that the } \\
\text { husbands should support their wives by positive behaviors so they will not think about bad things } \\
\text { on their babies and on themselves. }\end{array}$ \\
\hline
\end{tabular}

\section{Introduction}

Maternal mortality rate in Sumatera Utara in last 6 years showed the downward trend from 360 in every 100.000 live birth in 2002 into 345 in every 100.000 live birth in 2003, 330 dead in every 100.000 live birth in 2004, 320 in every 100.000 live birth in 2005, 315 in every 100.000 live birth in 2006 and 275 in every 100.000 live birth in 2007 (DINKES PROVSU, 2008).

We estimated that there were 342900 (uncertainty interval 302 100-394 300) maternal deaths worldwide in 2008, down from 526300 (446 400-629 600) in 1980. The global MMR decreased from $422(358-505)$ in 1980 to $320(272-388)$ in 1990, and was 251 (221-289) per 100000 livebirths in 2008. The yearly rate of decline of the global MMR since 1990 was $1 \cdot 3 \%(1 \cdot 0-1 \cdot 5)$. During 1990-2008, rates of yearly decline in the MMR varied between countries, from $8 \cdot 8 \%(8 \cdot 7-14 \cdot 1)$ in the Maldives to an increase of $5 \cdot 5 \%(5 \cdot 2-5 \cdot 6)$ in Zimbabwe. More than $50 \%$ of all maternal deaths were in only six countries in 2008 (India, Nigeria, Pakistan, Afghanistan, Ethiopia, and the Democratic Republic of the Congo) (WHO, 2008).
Maternity mortality rate based on SDKI in 2012 there are 359/100.000 live birth (KEMENKES RI, 2014).

Labor is a important occurance for parents and family. It's well knowing, easyness in labor is highly dependent on mothers condition but very important to know that there is almost no human behavior and biological progress unaffected by psychological condition. Fetal growth will make mother more easlliy exhausted, hard to sleep and breathless. Even the strongest woman felt the same thing.

Fear and too much worry would make concentration disturbance on preparing to facing labor. If this condition happend expectant mother would not have an optimal preparation to labor her first baby (Utami, 2009).] Every expectant mother who never give birth before would felt fear and worry more than expectant mother who had given birth (Ambarwati, 2001 dan Utami, 2009). The anxiety factor on mothers could make labor progress become longer and it will impact on morbidity and mortality rate because of painfull feeling (Nayak, 2014). Prolonged labor usually happened in first stage of labor. This stage is a progrees of servical dilatation until complete (American Pregnancy Association, 2015). 
Preliminary survey taken on Juli-September 2012 from several private maternity clinic in Dellitua Public Health Center working area showed: There are 94 nulliparous mothers and $42,55 \%$ from them experiencing normal lenght of first stage of labor (4-8 hour), 27,65\% experiencing prolonged first stage of labor (>8-12 hour), 10,63\% experiencing 20-24 hour first stage of labor, $19,15 \%$ referred to hospital because experiencing more than 24 hour. On the other side there are 112 mothers who had given birth, 79,46\% experiencing normal first stage of labor, $12,25 \%$ experiencing prolonged first stage of labor, 5,36 experiencing 12-16 hour first stage of labor and 2,68\% experiencing 16 hour first stage of labor and referred to hospital.

Based on these background, this study showed the correlation of the level of anxiety of nulliparous women to the length of first stage of spontaneous labor at Private Maternity Clinics in the Working Area of Delitua Puskesmas, Deli Serdang district in 2013.

\section{Research Method}

This is a quantitative study with explanatory method approached. This study located in private maternity clinic in Delitua Public Health Center working area, Deli Serdang District. The population is all first pregnant mother (nulliparous) will give birth in private maternity clinic in Delitua Public Health Center working area. The number of sample are 40 people taken by Accidental Sampling. Data's was analyzed using Chi- Square test.

\section{Result and Discussion}

\subsection{Respondents Characteristics Distributions}

\begin{tabular}{|l|c|c|}
\hline Respondents Characteristics & N & $\%$ \\
\hline Age (years) & 16 & 40,0 \\
\hline $18-21$ & 20 & 50,0 \\
\hline $22-25$ & 4 & 10,0 \\
\hline $26-29$ & & \\
\hline Religion & 23 & 57,5 \\
\hline Islam & 9 & 22,5 \\
\hline Catolik & 8 & 20,0 \\
\hline Protestan & & \\
\hline Ethnics & 16 & 40,0 \\
\hline Java & 12 & 30,0 \\
\hline Malay & 9 & 22,5 \\
\hline Batak Karo & 3 & 7,5 \\
\hline Batak Toba & 2 & 5,0 \\
\hline Marriage Status & 1 & 2,5 \\
\hline Married & & \\
\hline Unmarried & 39,5 \\
\hline Education & & \\
\hline Elementary & & \\
\hline
\end{tabular}

\begin{tabular}{|c|c|c|}
\hline Junior High School & 5 & 12,5 \\
\hline Senior High School & 29 & 72,5 \\
\hline College & 4 & 10,0 \\
\hline \multicolumn{3}{|l|}{ Occupatiom } \\
\hline Hosewifes & 29 & 72,5 \\
\hline Entrepreneur & 5 & 12,5 \\
\hline Teacher/lecture & 2 & 5,0 \\
\hline Farmer & 2 & 5,0 \\
\hline Housekeeper & 2 & 5,0 \\
\hline \multicolumn{3}{|l|}{ Income } \\
\hline$<$ Rp.1.500.000 & 28 & 70,0 \\
\hline Rp.1.500.000-Rp.3.000.000 & 6 & 15,0 \\
\hline Rp.3.100.000-Rp.4.500.000 & 6 & 15,0 \\
\hline \multicolumn{3}{|l|}{ Maternity Checkup } \\
\hline Once & 1 & 2,5 \\
\hline 2 times & 2 & 5,0 \\
\hline 3 times & 5 & 12,5 \\
\hline$>=4$ times & 32 & 80,0 \\
\hline \multicolumn{3}{|c|}{ Complaints During Pregnancy } \\
\hline Yes & 38 & 95,0 \\
\hline No & 2 & 5,0 \\
\hline
\end{tabular}

\subsection{Respondent Variable Distibutions}

Measuring result showed, number of nulliparous women whom experiencing normal duration of the first stage of labor about $(62,5 \%)$, and abnormal about (37,5\%). Anxiety levels meassured on nulliparous women in moderate level $(47,5 \%)$, hard $(50,0 \%)$, and panic $(2,5 \%)$.

Table 2: Variables Frequency Distributions

\begin{tabular}{|l|l|c|c|}
\hline No & \multicolumn{1}{|c|}{ Variable } & N & \% \\
\hline \multicolumn{3}{|c|}{ Dependent variable } \\
\hline 1 & Lenght of first stage \\
\hline & Normal & 25 & 62,5 \\
\hline & Abnormal & 15 & 37,5 \\
\hline \multicolumn{3}{|l|}{} \\
Independent variable \\
\hline 2 & Level of Anxiety & 19 & 47,5 \\
\hline & Moderate & 20 & 50,0 \\
\hline & Hard & 1 & 2,5 \\
\hline & Panic
\end{tabular}

1.3 Correlation of Level of Anxiety with Lenght of First Stage Labor at Private Maternity Clinics in the Working Area of Delitua Puskesmas, Deli Serdang District in 2013

Chi Square test result showed there is a correlation between anxiety level with length of the first stage spontaneous labor primigravidae with $\mathrm{p}=0,001$. 
Table 3: Correlation of Level of Anxiety with Lenght of

First Stage Labor at Private Maternity Clinics in the

Working Area of Delitua Puskesmas, Deli Serdang District in 2013

\begin{tabular}{|l|c|c|c|c|c|c|c|}
\hline \multirow{2}{*}{$\begin{array}{c}\text { Level Of } \\
\text { Anxiety }\end{array}$} & \multicolumn{4}{|c|}{ Lenght of First Stage Labor } & \multicolumn{2}{c|}{ Total } & \multirow{2}{*}{$\boldsymbol{P}$} \\
\cline { 2 - 6 } & \multicolumn{2}{|c|}{ Normal } & \multicolumn{2}{c|}{ Abormal } & \multicolumn{2}{|c|}{} \\
\cline { 2 - 7 } & $\mathbf{n}$ & $\mathbf{\%}$ & $\mathbf{n}$ & $\mathbf{\%}$ & $\mathbf{n}$ & $\%$ & \\
\hline Moderate & 17 & 89,5 & 2 & 10,5 & 19 & 100,0 & 0,001 \\
\hline Hard+Panic & 8 & 38,1 & 13 & 61,9 & 53 & 100,0 & \\
\hline Total & $\mathbf{2 5}$ & $\mathbf{6 2 , 5}$ & $\mathbf{1 5}$ & $\mathbf{3 7 , 5}$ & $\mathbf{4 0}$ & $\mathbf{1 0 0 , 0}$ & \\
\hline
\end{tabular}

Table 3 showed a significant correlation between level of anxiety with lenght of first stage spontaeus labor, mother's anxiety from nulliparous women had gave contribution to lenght of first stage labor it usually happened because of many pressure, high anxiety, unstability feeling and own fear felling if baby's born in abnornal condition, birth defects or died. Sometimes, young mothers felt too worry about how to caring a baby. Moreover women who did not get attention and moral support from family especially husband are easily getting anxiety in labor.

These result is coressponding with Jatmika Research in 1999 who found a high correlation between anxiety with lenght of first stage of labor and vice versa (Jatmika, 1999).] Anxiety will more higher by the time give birth. This situation will make mothers become not cooperatif. Stress in labor and reflex can causing increased level of mothers chatekolamin. Psychologycal stress and hipokxia related to pain and anxiety would increase adrenaline secretion. Adrenaline secretion increasing would make a vaso kontriksi as a result uterus blood stream would decrease and finally, hipoksia happend, labor complication occur and last, fetal death (Chapman, 2006).

\section{Conclusion}

Univariat analysis from length of first stage of labor showed 25 respondent $(62,5 \%)$ experiencing normal length of first stage of labor and 15 respondent $(37,5 \%)$ experiencing abnormal lenght of first stage labor. Bivariat analysis showed theres a significant correlation between level of anxiety with lenght of fisrt stage labor with $\mathrm{pm}=0,001$.

\section{References}

- Ambarwati, E. R. (2001). Faktor-Faktor Yang Mempengaruhi Kecemasan Pada Ibu Primigravida. Dibuka pada website: http://enreynaambarwati.blogspot.com/201 0/04/faktor2-yang-mempengaruhi kecemasan.html. pada tanggal 18 Mei 2010.

- American Pregnancy Association. (2015). Prolonged Labor : Failure To Progress.

- Chapman, V. (2006). Asuhan Kebidanan: Persalinan dan Kelahiran. Jakarta: EGC. Dinas Kesehatan Provinsi Sumatera Utara. (2008). Profil Dinas Kesehatan Provinsi Sumatera Utara.
- Jatmika, W. (1999). Hubungan Skor Kecemasan dengan Lama Persalinan Kala I. Tesis. Semarang: Bagian/SMF Obstetri Ginekologi Fakultas Kedokteran Universitas Diponegoro Kementerian Kesehatan RI. (2014). Info Data dan Informasi.http://www.depkes.go.id/resourc es/download/pusdatin/infodatin/infodatinibu.pdf. Jakarta Selatan. Pusat Data dan Informasi.

- Nayak, D. at. All. (2014). Efectiveness Of Music Therapy Level, and Pain Perseption In Primipara Mothers During First Stage Of Labor In Selectes Hospitals of Odisha. Journal Of Nursing And Health Science (IOSR/JNHS). Vol. 3, Issue 2, Versi 5.

- Utami, D. A. (2009). Efektifitas Aromaterapi dalam Menurunkan Kecemasan Menghadapi Kelahiran Anak Pertama. Dibuka pada website: http:// www.pdfio.com/k-1168441.html\# openned on 10 February 2013.

- $\quad$ WHO. (2008). Maternal mortality for 181 countries, 1980-2008: a systematic analysis of progress towards WHO. 2008. Maternal mortality for 181 countries, 1980-2008: a systematic analysis of progress towards 